\title{
Development and standardization of the Dot Blot test for serological diagnosis of
}

\section{bovine leptospirosis}

\author{
Desenvolvimento e padronização do teste Dot Blot para diagnóstico sorológico de leptospirose \\ bovina
}

Desarrollo y estandarización de la prueba Dot Blot para el diagnóstico sorológico de la leptospirosis bovina

\begin{abstract}
Leptospirosis a public health problem and an endemic zoonosis in Brazil, is diagnosed by serological methods. Therefore, low-cost and easy to execute methodologies with good/high sensitivity, such as Dot Blot, are an important diagnostic tool. The aim of this study was to standardize and validation the dot-blot technique for the serological diagnosis of bovine leptospirosis. Several concentrations of antigens applied to nitrocellulose membranes, and different dilutions of conjugated bovine serum were evaluated to develop and standardize the test. The best distinction/contrast between positive and negative samples was observed for $1 \mu \mathrm{L}$ antigen $(0.11 \mu \mathrm{g} / \mu \mathrm{L}$ outer membrane protein of the Hardjo serovar (OMPH) and $0.08 \mu \mathrm{g} / \mu \mathrm{L}$ outer membrane protein of the Wolffi serovar (OMPW)), 1:500 and 1:10000 bovine serum dilution and conjugate, respectively. The Dot Blot test efficiency was $71.87 \%$ and kappa index, $0.46(\mathrm{p}<0.0001)$. The other parameters measured were: sensitivity $91.89 \%$; specificity $59.32 \%$; positive predictive value $58.62 \%$; and, negative predictive value $59.32 \%$. In addition to high sensitivity, other advantages of the Dot Blot technique have been identified, such as practicality, low cost since it does not require sophisticated devices and the fact that the Hardjo and Wolffi OMP also reacted with serovars from other pathogenic serogroups. The results provided positive expectations for the use of Dot Blot as support in the diagnosis of bovine leptospirosis, especially if used as a screening test, stimulating further research for the future development of kits for diagnostic purposes.
\end{abstract}

Keywords: Dot-ELISA; Sensitivity, Leptospira spp.; MAT; Immunodiagnostics.

\section{Resumo}

A leptospirose, zoonose endêmica no Brasil e problema de saúde pública, é diagnosticada por métodos sorológicos. Metodologias tais como o Dot Blot, assumem papel importante devido a fácil execução, baixo custo e sensibilidade. Com o objetivo de padronizar um teste Dot Blot para o sorodiagnóstico da leptospirose bovina, utilizou-se como antígeno proteínas de membrana externa (PME) dos sorovares Hardjo e Wolffi, e 96 amostras de soro bovino, previamente testados na soroaglutinação microscópica (SAM). Para o desenvolvimento e padronização do teste foram avaliadas diferentes concentrações de antígenos aplicadas em membranas de nitrocelulose, além de diferentes diluições de soro bovino e conjugado, sendo que a melhor distinção entre amostras positivas e negativas se deu com 
$1 \mu \mathrm{L}$ de antígeno $(0,11 \mu \mathrm{g} / \mu \mathrm{L}$ de proteína de membrana externa do sorovar Hardjo (PMEH) e $0,08 \mu \mathrm{g} / \mu \mathrm{L}$ de proteína de membrana externa do sorovar Wolffi (PMEW)), o soro bovino na diluição 1:500, e conjugado em 1:10000. Ao avaliar o desempenho do teste de Dot Blot, obteve-se eficiência de 71,87\% e índice kappa de 0,46 (p<0,0001). Observou-se sensibilidade de $91,89 \%$, especificidade de 59,32\%, valor preditivo positivo de $58,62 \%$ e o valor preditivo negativo de 59,32\%. Além da alta sensibilidade, outras vantagens foram identificadas na técnica de Dot Blot, como praticidade, baixo custo por dispensar aparelhagem sofisticada e o fato das PME de Hardjo e Wolffi também induzirem reação com sorovariedades de outros sorogrupos patogênicos. Os resultados proporcionaram expectativas positivas para o uso do Dot Blot como suporte no diagnóstico para a leptospirose bovina, principalmente se utilizado como teste de triagem, estimulando a continuidade de pesquisas para que, futuramente, desenvolvam-se kits com fins diagnósticos.

Palavras-chave: Dot-ELISA; Sensibilidade; Leptospira spp.; SAM; Imunodiagnóstico.

\section{Resumen}

La leptospirosis es una zoonosis endémica en Brasil y un problema de salud pública. Metodologías como Dot Blot, detener un papel importante porque es fácil de realizar, de bajo costo y sensibilidad. Se utilizaron proteínas de membrana externa (SMEs) de serovares Hardjo y Wolffi, para estandarizar una prueba Dot Blot para el serodiagnóstico de leptospirosis bovina. Fueron usados 96 muestras de suero bovino, previamente testeado en aglutinación microscópica de suero (SAM). Se evaluaron diferentes concentraciones de antígenos aplicados a membranas de nitrocelulosa, además de diferentes diluciones de suero bovino y conjugado, y la mejor distinción entre muestras positivas y negativas fue con $1 \mu \mathrm{L}$ de antígeno $(0.11 \mu \mathrm{g} / \mu \mathrm{L}$ de proteína de la membrana externa del serovar Hardjo (PMEH) y 0,08 $\mu \mathrm{g} / \mu \mathrm{L}$ de proteína de la membrana externa del serovar de Wolffi (PMEW), bovino a una dilución de 1: 500 y conjugado a 1: 10000. Al evaluar el desempeño de la prueba Dot Blot se obtuvo una eficiencia del 71,87\% y un índice kappa de 0,46 (p <0,0001), sensibilidad del 91,89\%, especificidad del 59,32\%, valor predictivo positivo del $58,62 \%$ y un valor predictivo negativo del 59,32\%. Además, se identificaron otras ventajas, como la practicidad, bajo costo de dispensación de equipos sofisticados y de que las pymes de Hardjo y Wolffi también inducen una reacción con serovariedades de otros serogrupos patógenos. Los resultados arrojaron expectativas positivas para el uso de Dot Blot como soporte en el diagnóstico de leptospirosis bovina, especialmente si se utiliza como prueba de cribado, estimulando la continuidad de la investigación para que, en el futuro, se puedan desarrollar kits con fines diagnósticos.

Palabras clave: Dot-ELISA; Sensibilidad; Leptospira spp; SAM; Inmunodiagnóstico.

\section{Introduction}

Leptospirosis is a worldwide disseminated zoonosis (Quinn, Markey, Carter, Donnelly, \& Leonard et al., 2005). It is considered a public health problem and more common in developing countries (Bharti et al., 2003). This disease is caused by pathogenic bacteria of the genus Leptospira; it is endemic in Brazil and occurs all year round (Brasil, 2009).

Initially, the genus Leptospira, was classified than L. interrogans and L. biflexa ( pathogenic and non-pathogenic species), based on the presence of homologous antigens (nearly 60 serovars under L. biflexa and at least 225 serovars under L. interrogans). But later on, at least 21 more species have been identified under Leptospira with more than 200 specific serovars. Sanrot 2021). Despite the fact that several serovars have been described as causing bovine leptospirosis, serological surveys in Brazil demonstrate the predominance of serovars Hardjo and Wolffi, the first being the most prevalent (Araújo, Moreira, Silva, \& Contreras., 2005; Favero et al., 2001; Lage et al., 2007; Lilenbaum \& Souza, 2003;; Marques et al., 2010).

Studies have meant that leptospirosis is prevalent in Brazilian herds, showing $6.76 \%$; $11.8 \%$; in the south, northeast regions of the country, respectively (Dewes et al., 2020b; Pimenta et al., 2019; Sanches et al., (2018) analyzed blood samples of 11 herds (representing 400 animals of São Paulo, Brazil.) and 66\% of animals were positive to definitive serological test against at least one pathogen serogroup of Leptospira spp. definitive serological test. Magalhães et al. (2020), determined the prevalence of bovine leptospirosis in the Triângulo Mineiro region, Minas Gerais, Brazil, identified $48 \%$ of the cows were reagents for the Wolffi, Hardjo and Hebdomadis serovars in a large number of rural properties.

Several serological tests are used to diagnose bovine leptospirosis, such as ELISA, complement fixation, and immunofluorescence microscopy, but the definitive serological test is the microscopic agglutination test (MAT), according to the International Organization for Animal Health (OIE) (Who, 2003; Levett, 2004). However, it is a laborious and potentially 
risky test since several serovar cultures must be kept alive in a liquid medium (Levett, 2004; Quinn et al., 2005). Also, the risk of cross-contamination between antigens makes necessary to check periodically for contamination of the culture medium, which can affect the titration results of the test (Sykes et al., 2011).

Current diagnostic techniques, such as MAT and even the polymerase chain reaction (PCR), are not entirely satisfactory. Although the leptospirosis diagnosis is confirmed, the tools required to perform the tests are restricted to laboratories with high infrastructure costs. For this reason, there is a need to develop rapid, sensitive, and specific tests that can facilitate the diagnosis and require fewer resources to be implemented (Picardeau, 2013).

The Dot Blot test, also known as dot-blot ELISA, dot immunobinding assay, is a technique based on the sensitization of the nitrocellulose membranes (NM) with specific antigens, subjecting them to the reaction with the primary (serum) and secondary antibody, marked with peroxidase to develop coloring. The principle is similar to ELISA, with the additional advantages of high sensitivity, convenience, and low cost, since it does not require sophisticated equipment (Pinheiro, 2001; Pinheiro, Olortegui, Gouveira, Araujo, \& Andrioli, 2006). The Dot Blot test is a potential tool for diagnostic purposes; however, there are few reports of its use to detect leptospirosis.

Several known proteins play an important role in the virulence of pathogenic Leptospira, among them the outer membrane proteins (OMP), which, because they induce immune response, constitute a good resource for the development of diagnostic tests (Cullen, Xu, Matsunaga, Sanchez, Ko, Haake, \& Adler, 2005; Haake, 2000; Levett, 2004; Zuerner, Haake, Adler, \& Segers, 2000).

The aim of this study was to standardize and validation the dot-blot technique for the serological diagnosis of bovine leptospirosis, using as an antigen the outer membrane proteins (OMP) of the Hardjo and Wolffi.

\section{Methodology}

\subsection{Sampling}

The 96 serum samples analyzed in this study were collected from cattle in the region of Uberlândia, MG. The samples were analyzed in the infectious diseases laboratory at the School of Veterinary Medicine (FAMEV) of the Universidade Federal de Uberlândia (UFU).

\subsection{Microscopic Agglutination Test (MAT)}

Cattle serum samples were considered reagent to MAT from the 1:100 cutoff dilution and above (Faine, Adler, Bolin, \& Perolat, 1999). A total of 14 serovars were used, as follows: Autumnalis, Australis, Bataviae, Bratislava, Canicola, Copenhageni, Grippothyphosa, Hardjo, Hebdomadis, Icterohemorrhagiae, Pyrogenes, Pomona, Tarassovi and Wolffi. The results were the main parameters used to develop and standardize the Dot Blot technique.

\subsection{Antigen production}

To produce the antigen (OMP), the Hardjo and Wolffi serovars were grown in Ellinghausen - McCullough - Johnson Harris (EMJH - DIFCO) liquid medium, supplemented with $10 \%$ sterile rabbit serum, free of anti-leptospira antibodies, and incubated for seven days at $30^{\circ} \mathrm{C}$ (Brasil, 1995; Magalhães et al., 2006). The OMP was extracted following the modified Lafetá et al. methodology (Lafetá et al., 2008).

A volume of $250 \mathrm{ml}$ of the Hardjo serovar culture was centrifuged at $8,000 \times \mathrm{g}\left(15\right.$ minutes at $\left.4^{\circ} \mathrm{C}\right)$ and the supernatant discarded. The pellet was resuspended three consecutive times in $2 \mathrm{~mL} \mathrm{PBS} \mathrm{(pH} \mathrm{7.2)} \mathrm{containing} 5 \mathrm{mM} \mathrm{MgCl}_{2}$, and then three more times in $2 \mathrm{~mL}$ TE buffer (10 mM Tris hydrochloride - $2 \mathrm{mM}$ EDTA, pH 7.4). Subsequently, $1 \%$ Triton X114 (Sigma-Aldrich) (v/v) was added and incubated at $4{ }^{\circ} \mathrm{C}$ for 30 minutes. Then, centrifuged at $8,500 \mathrm{xg}\left(10\right.$ minutes at $\left.4^{\circ} \mathrm{C}\right)$. The 
supernatant was collected, and $2 \%$ Triton X114 (v/v) was added. The mixture was heated at $37^{\circ} \mathrm{C}$ for 10 minutes in a water bath, centrifuged at $2,000 \times \mathrm{g}\left(10\right.$ minutes at $\left.25^{\circ} \mathrm{C}\right)$ and the aqueous and detergent phases were separated using a micropipette. After separation, the two phases were placed in an ice bath for 10 minutes, followed by the addition of $60 \mu \mathrm{L}$ Triton X114 to the aqueous phase and $2 \mathrm{~mL}$ T.E. ( $\mathrm{pH} \mathrm{7.4)} \mathrm{to} \mathrm{the} \mathrm{detergent} \mathrm{phase,} \mathrm{which} \mathrm{were} \mathrm{then} \mathrm{centrifuged} \mathrm{at} 3,000 \mathrm{x}$ ( $10 \mathrm{minutes}$ at $4^{\circ} \mathrm{C}$ ). This procedure was repeated three times. The proteins were precipitated with 10 volumes of acetone (Vetec, PA) in an ice bath for 45 minutes and thereafter, the two fractions were centrifuged at $12,600 \mathrm{x} \mathrm{g}$ at $4^{\circ} \mathrm{C}$ for 30 minutes. The acetone present in the supernatant was discarded, and the pellet suspended in $1 \mathrm{~mL}$ of ultrapure water. This solution was divided into aliquots and stored at $-20^{\circ} \mathrm{C}$ until analysis. The procedure was repeated with $250 \mathrm{ml}$ of Wolffi serovar culture.

The extracted solutions were subjected to AMICON system, diluted in PBS, in an ultrafiltration Ultracel - 10k Millipore® cell (Pinheiro, Gouveia, Yorinori, \& Andrioli, 2005). Finally, the extracted proteins were measured following the Bradford (1976) method, set at $595 \mathrm{~nm}$ in a spectrophotometer using bovine serum albumin (BSA) as standard.

\subsection{Standardization of the dot blot test}

The test was developed in three steps as follows (Jacobson, 1998): (I) checking test feasibility; (II) test development and optimization; (III) performance assessment.

\subsubsection{Feasibility}

To verify the test feasibility, ten non-hemolyzed serum samples (Jacobson, 1998), of which six positive and four negative according to MAT results, were used. The antibody titers ranged from low to high and were positive for both Hardjo and/or Wolffi serovars, acknowledging, however, the simultaneous occurrence of Hebdomadis serovar.

MAT negative samples were from healthy calves up to three months old and unvaccinated against bovine leptospirosis. Positive samples had titers of 1:100 (Wolffi), 1:200 (Hardjo), 1:400 (Hardjo and 1:100 Hebdomadis), 1:800 (Hardjo) and 1:1600 (Hardjo and 1:400 Hebdomadis), and a sample highly reactive to 4 serovars simultaneously in high titratable levels (Grippothyphosa 1:200, Hardjo 1:1600, Hebdomadis 1:1600 and Wolffi 1:200). The method was developed using the ten samples described above.

\subsubsection{Development}

The development of the Dot Blot technique was based on the methodology described by Fenoll, Jado, Vicioso, \& Casal et al. (1997), following the OIE recommendations for the standardization of equipment and apparatus. The NM (nitrocellulose membrane, Santa Cruz Biotechnology, $0.22 \mu \mathrm{M}$ pore - Ultra Cruz SC - 3718) was cut into thin strips of approximate dimensions 0.6 × $6 \mathrm{~cm}$, and sensitized with pipette-applied purified bovine immunoglobulin G (IgG) obtained from bovine with leptospirosis; outer membrane protein of the Hardjo serovar (OMPH); outer membrane protein of the Wolffi serovar (OMPW); and BSA, disposed separately according to the scheme shown in section 7 of Figure 1 . The IgG and BSA were used as positive and negative control, respectively, in all the strips. Three different concentrations of the antigenic portion, $0.5 \mu \mathrm{L}, 1 \mu \mathrm{L}$ and $2 \mu \mathrm{L}$ of OMPH and OMPW solution, were used to assess the optimal concentration of antigen in the NM sensitization.

After sensitized and dried, the NMs were transferred to an eight channel hydrophobic plastic support, and blocked in each channel using $1 \mathrm{~mL}$ of PBS buffer with 5\% milk powder (PBSM) during one hour at room temperature in Kline agitator (TS - 2000 A VDRL SHAKER) at minimum speed. As a control, one channel was always used for an NM strip sensitized only with BSA to control buffer contamination. Subsequently, the NM was washed in $1 \mathrm{~mL}$ PBS buffer (pH 7.2) for 1 minute while stirring constantly. Then, the test serum (primary antibody) was added to $1 \mathrm{~mL}$ PBS buffer containing $0.05 \%$ Tween 20 and 
5\% skimmed milk powder (PBSTM), and incubated for one hour at minimum speed in the Kline shaker. To evaluate the best dilution of test serum, the following dilutions were used 1:50, 1:100, 1:200, 1:300, 1:400, 1:500, 1:600, 1:700, 1:800 and $1: 1000$.

The strips were washed three times with $1 \mathrm{ml}$ PBS containing 0.05\% Tween 20 (PBST) for 2 minutes, under stirring. Three different washing times were used (1, 2 and 5 minutes). Subsequently, the peroxidase conjugated anti-rabbit $\operatorname{IgG}$ antibody was diluted in $1 \mathrm{~mL}$ PBSTM solution for 60 minutes, stirring constantly. The strips were washed three more times with PBST for 2 minutes in the shaker. The dilutions 1:5000 and 1:10000 were tested to determine the optimal dilution of conjugate antibody.

The color was developed by adding $1 \mathrm{~mL}$ of the developing solution (15 mL TrisNaCl, 0.01g DAB [3,3'Diaminobenzidine (DAB) -. Sigma Cat. $\mathrm{n}^{\circ}$ D5637] and $12 \mu$ L peroxide hydrogen) to each channel in the dark while stirring for 5 minutes. The samples were considered positive for bovine leptospirosis when the color changed for one or both OMPs.

\subsubsection{Assessment}

A total of 96 bovine serum samples previously tested by MAT were used to evaluate and standardize the proposed methodology. The NMs were coated with bovine IgG, OMPH, OMPW and BSA, and prepared as shown in Fig.1b. The 96 samples were tested to evaluate the test performance compared to the gold standard. The test efficiency, sensitivity and specificity relative values, positive and negative predictive values and the degree of agreement using the Kappa index, were obtained using the Bioestat 5.0 software, always referring to the results achieved in the microscopic agglutination test in dark field (Armitage, Berry, \& Matthews, 2008; Jacobson, 1998; Ferreira \& Ávila, 2001; Ayres, Ayres Júnior, Ayres, \& Santos, 2007).

\section{Results and Discussion}

Figure 1 shows the results for the different antigen concentrations (PMEH and PMEW) used in the nitrocellulose membrane during the standardization process. The antigen production resulted in a total volume of $600 \mu \mathrm{L}$ for each OMP serovar, with concentrations of 0.11 and $0.08 \mu \mathrm{g} / \mu \mathrm{L}$ for $\mathrm{OMPH}$ and $\mathrm{OMPH}$, respectively. The best results for the washing with PBST buffer were observed in 2 minutes since the negative control samples were still lightly colored in 1 minute. On the other hand, the positive control samples lost color after 5 minutes. 
Figure 1 - Results for the standardization of the antigen concentrations (OMPH and OMPW) in the Dot Blot test.
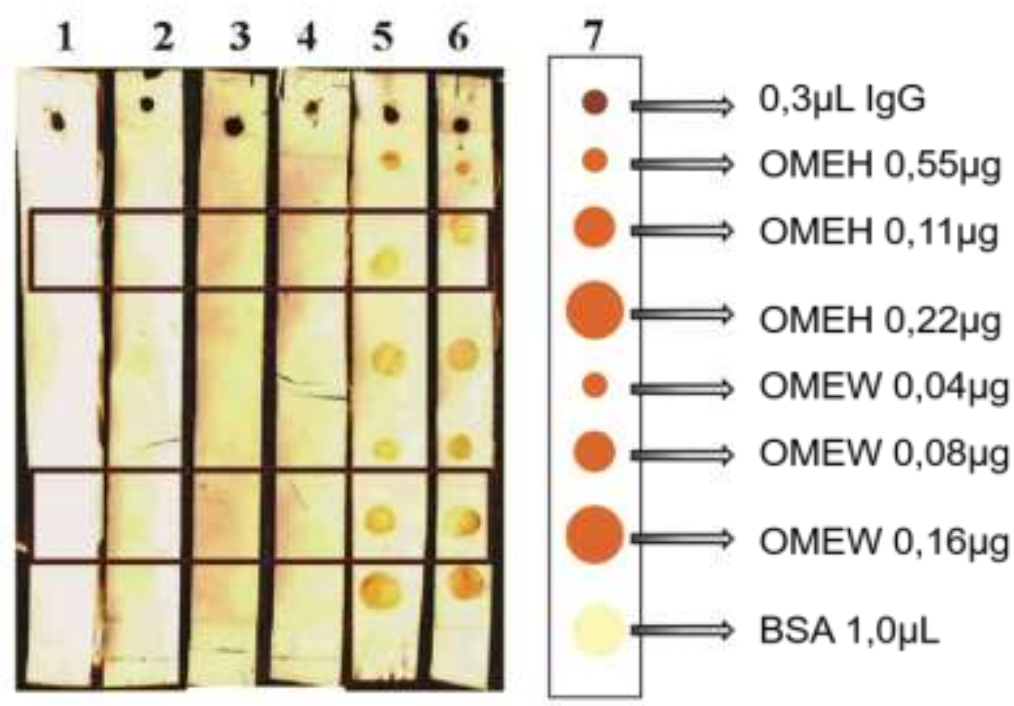

1 and 2: Blank controls; 3 and 4: Negative samples; 5 and 6: Positive samples. The highlighted images show OMP reaction to $1 \mu \mathrm{L}$ of antibodies; 7: Scheme of the disposition of antigens (OMEW and OMEH), bovine serum albumin (BSA) and immunoglobulins (IgG), used for sensitization of the Nitrocellulose Membrane to evaluate the best visual distinction of antibody titers in the test. Source: Authors.

Figure 2 shows the results obtained in the standardization of serum dilution for the control, positive and negative samples (background).

Figure 2 - Results obtained for the standardization of the serum dilution. L: NM sensitization layout.

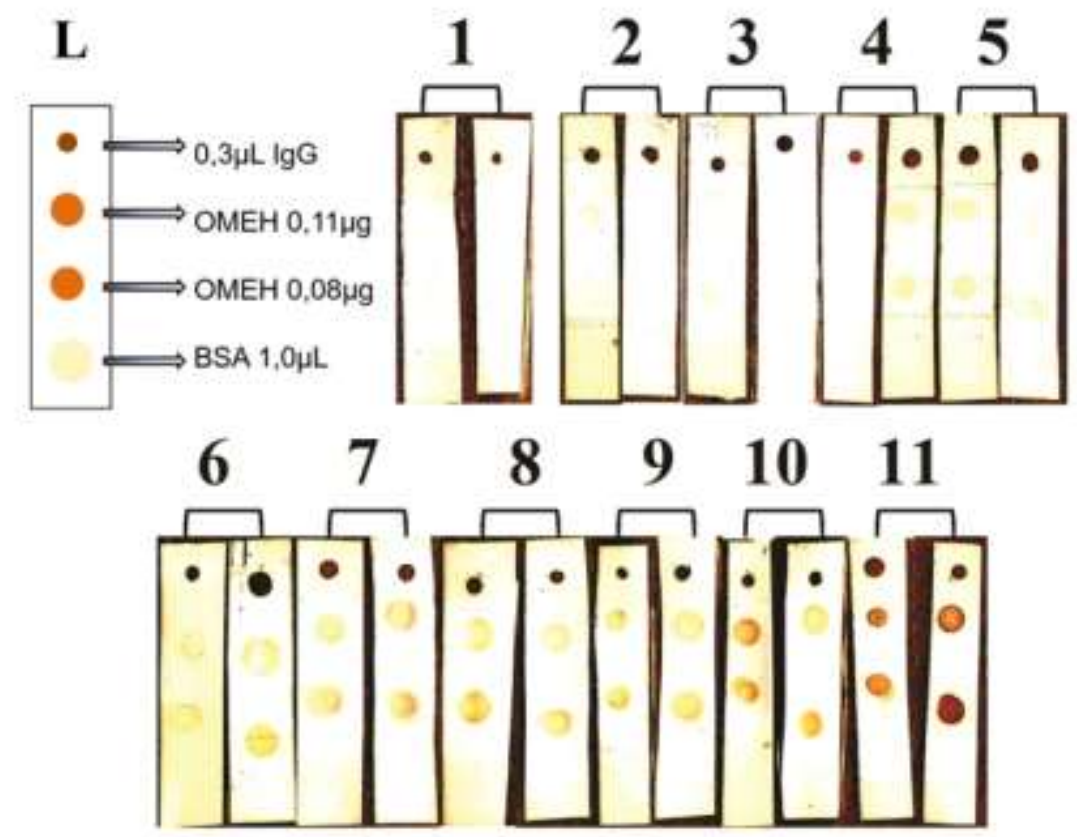

1: Control sample; 2, 3, 4 and 5: negative samples from unvaccinated calves up to 3 months old; 6: sample positive for Wolffi, with 1:100 titer (MAT); 7: Sample positive for Hardjo, with 1:200 titer (MAT); 8: sample positive for Hardjo and Hebdomadis with 1:400 and 1:100 titers, respectively (MAT); 9: sample positive for Hardjo with 1:800 titer (MAT); 10: Sample Positive for Hardjo and Hebdomadis, with 1:1600 and 1:400 titers, respectively (MAT); 11: Sample Positive for several serovars, Grippothyphosa, Hardjo, Hebdomadis and Wolffi with 1:200, 1:1600, 1:1600, 1:200 titers, respectively (MAT). Source: Authors. 
The best results were obtained using $1 \mu \mathrm{L}$ antigen solution (OMP) to sensitize the NM with $1 \mathrm{~mL}$ primary antibody (test serum) diluted to 1:500 and $1 \mathrm{~mL}$ conjugate antibody diluted to 1:5000. This combination best distinguished the positive and negative samples, especially negative samples and those positive but with low titers such as 1:100.

The efficiency of the Dot Blot test was determined by comparing the test results with a total of 96 samples previously analyzed by MAT. The MAT results showed that 37 (38\%) samples were positive and 59 (62\%) negative. The titers were calculated as the highest dilution of serum that had at least $50 \%$ agglutination in each evaluated serogroup. These same samples were subjected to Dot Blot, and the results showed that 58 (60\%) were positive, and 38 (40\%) negative.

The analysis of test performance showed $71.87 \%$ efficiency, $91.89 \%$ sensitivity and $59.32 \%$ relative specificity. The predictive values were $58.62 \%$ and $59.32 \%$ for positive and negative samples, respectively (Table 1 ).

The comparison of the results from the MAT and Dot Blot tests shows $71.9 \%$ agreement and 0.46 kappa index $(\mathrm{p}<0.0001)$, according to the Bioestat 5.0 software (Table 1).

Table 1 - Comparison of the results of serum samples tested by microscopic agglutination test (MAT) and Dot Blot for serological diagnosis of bovine leptospirosis

\begin{tabular}{cccc}
\hline Dot Blot & \multicolumn{3}{c}{ Microscopic Agglutination Test (MAT) } \\
\cline { 2 - 4 } & Positives & Negatives & Total \\
\hline Positives & 34 & 24 & 58 \\
Negatives & 3 & 35 & 38 \\
Total & 37 & 59 & 96 \\
\hline
\end{tabular}

Sensitivity $=91.89 \% ;$ Specificity $=59.32 \% ;$ Agreement $=71.9 \% ;$ kappa $=0.46$. Source: Authors .

\section{Discussion}

All antigen concentrations used to sensitize the MN caused the color to change in all serum dilutions (Figure 1), regardless of titrable levels of antibodies (Figure 2). However, $1 \mu \mathrm{L}$ OMP resulted in the best color definition compared to others. Therefore, $1 \mu \mathrm{L}$ antigen ( 0.11 and $0.08 \mu \mathrm{g} / \mu \mathrm{L}$ for OMPH and OMPH) was used to perform one test and, in this case, the protein extract had good yield, the initial $250 \mathrm{ml}$ culture produced antigen to perform 600 tests. Dewes et al. (2020) standardized the dot blot test for bovine leptospirosis with the use of inactivated antigen suspended in PBS buffer and obtained satisfactory results with $10 \mathrm{uL}$.

The best results for (PBST) buffer washing after adding the tested serum samples was 2 minutes. At 1 minute, samples with low titers could not be distinguished from the negative samples and/or nonspecific reactions. The Tween 20 buffer, the surfactant component, removes nonspecific antibodies, especially when present in small amounts or weakly bound to hydrophobic substrates such as nitrocellulose (Juhl, Nørgaard, \& Bjerrum, 1984). The 1-minute wash did not allow the Tween 20 to remove satisfactorily non-specific antibodies bound to the substrate.

On the other hand, even the color of samples with high antibody titers was washed away after 5 minutes. Samples with low antibody titers (1:100) became indistinguishable from the negative ones. The 2-minute wash allowed a more balanced result. The negative samples were evident, and the positive samples with high or low antibody levels were easily distinguishable as well (Figure 2).

The samples positive for Canicola, Hebdomadis, Icterohemorrhagiae and tarassovi serovars according to MAT, were also positive in the Dot Blot test and not different from the samples positive only to either Hardjo or Wolffi serovars, even though only the OMPs of the Hardjo and Wolffi serovars were used in the testing. Unlike the LPS, the OMPs were preserved 
between different $L$. interrogans serovars (Faine et al., 1999; Levett, 2004), and the OMPs of the Hardjo serovar are similar to the outer membrane protein profile of other serovars (Lafetá et al., 2008).

These results show that the Dot Blot test using the OMPH and OMPW can detect anti-Leptospira spp. antibodies in the serum regardless of the serovar involved. Souza et al. (2012) standardized and validated the indirect ELISA test using the OMP of the Hardjo serovar as antigen (ELISA-OMP/Hardjo), which evidenced the potential of the Hardjo membrane proteins to be applied in diagnostic screening of bovine leptospirosis with $100 \%$ sensitivity and $73 \%$ specificity.

The MAT technique is considered to have low sensitivity, especially in the acute phase, and its interpretation is hampered by the high degree of cross-reactivity between different serogroups (Levett, 2004). It is, therefore, better classified as serogroup-specific test rather than serovar-specific since it does not guarantee specificity when the serovars belong to the same sorogroup (WHO, 2003).

The test showed high sensitivity (91.89\%) and a potential to detect highly infected animals. It is appropriate to assist the diagnosis of bovine leptospirosis, especially if used as a screening test followed by another test with greater specificity. The positive and negative predictive values were $58.62 \%$ and $59.32 \%$, respectively. Dewes et al. (2020) observed similar results, with $94 \%$ sensitivity, and $53 \%$ specificity.

Agreement of 71.9\% was observed between MAT and Dot Blot tests and kappa index of 0.46 ( $p<0.0001$ ), with good reproducibility. The kappa index suggests that the observed difference between the results did not occur randomly, which indicates moderate but significant (Fenoll et al., 1997) test reproducibility.

Compared to MAT, in this study was possible to observe lower cost, less time and dispenses with the need for laboratory equipment. Similar results were shown by Dewes et al. (2020), However, they used 10uL of antigen while in this study only $1 \mathrm{uL}(0.11$ and $0.08 \mu \mathrm{g} / \mu \mathrm{L}$ for OMPH and OMPH) was used.

The good yield, since the antigen produced from $250 \mathrm{~mL}$ of Leptospira spp. culture allowed to perform 600 tests, the antigen's ability to sensitize the NM and induce satisfactory answer, indicate that the Dot Blot test is feasible. Similar results were found by Dewes et al. (2020a)

As reported in recent research this technique had proving suitable for the serological diagnosis other diseases, with the bovine brucellosis, the antigen adheres to the center of the nitrocellulose membrane, which ensures the use of an established antigen concentration, and its simplicity, precision and speed demonstrated that the assay can be used in the field for large scale diagnosis (Bastos et al., 2018).

The test is also convenient, low cost and does not require sophisticated equipment (Pinheiro et al., 2006). It is possible to analyze large numbers of samples under unfavorable conditions (Bamdad, Rodstai, Solimandjahi, \& Malekaneh, 2001) since nitrocellulose technical characteristics allow its successful use in field studies and minimally equipped laboratories (Rossi, Tsang, \& Pilcher, 1991).

The hydrophobic plastic support prevents leakage of substances (antigens, antibody, buffers) from one well to another, which would cause cross-reactions (Lin \& Halbert, 1986). The stability of the NM adhered antigen enables to use this test in the field (Hebeling \& Kalter, 1986).

The development of diagnostic kits with NM sensitized with OMPs of several serovars would allow veterinarians to conduct field screening tests to detect cattle serum reagent to bovine leptospirosis, conveniently and with no need for sophisticated equipment.

\section{Conclusion}

The Hardjo and Wolffi OMPs were effective antigens in enzyme immunoassays to detect antibodies to bovine leptospirosis regardless of the infecting serovar. 
The Dot Blot test standardized in this study proved to be feasible for the serological diagnosis of bovine leptospirosis, using the MAT as a reference, particularly if used as a screening test followed by a test with higher specificity. The Dot Blot test sensitivity is promising as an alternative for the diagnosis of bovine leptospirosis. Further studies are necessary to determine the feasibility of developing a diagnostic kit containing nitrocellulose membranes coated with OMPs of various serovars.

\section{Acknowledgments}

This research was funded by National Council for Scientific and Technological Development (CNPq), the Ministry of Agriculture, Livestock and Food Supply (MAPA) and the Secretariat of Agricultural Protection (SDA), through approval No. 64/2008; and by Program Tutorial Education (PET) from Department of Higher Education of the Ministry of Education MEC and the Federal Agency for the Support and Improvement of Higher Education - Brasil (CAPES) -Finance Code 001.

\section{References}

Araújo, V. E. M., Moreira, E. C., Silva, J. A., \& Contreras, R. L. (2005). Freqüência de aglutininas anti-Leptospira interrogans em soros sangüíneos de bovinos, em Minas Gerais, de 1980 a 2002. Arquivo Brasileiro de Medicina Veterinária e Zootecnia, 57(4), 430-435.

Armitage, P., Berry, G., \& Matthews, J. N. S. (2008). Statistical methods in medical research. John Wiley \& Sons

Ayres, M., Ayres Júnior, M., Ayres, D. L., \& Santos, A. D. A. (2007). Bioestat 6.0: aplicações estatísticas nas áreas das ciências biomédicas. Belém: Sociedade Civil Mamirauá MCT - CNPq.

Bamdad, T., Rodstai, M., Solimandjahi, H., \& Malekaneh, M. (2001). Application and adaptation of dot immunoassay to detect and measure rubella virus antibody. Medical Journal of The Islamic Republic of Iran (MJIRI), 15(3), 171-174.

Bastos, C. R., Mathias, L. A., Jusi, M. M. G., Santos, R. F. D., Silva, G. C. P. D., André, M. R. et al. (2018). Evaluation of dot-blot test for serological diagnosis of bovine brucellosis. Brazilian journal of microbiology, 49(3), 564-568.

Bharti, A. R., Nally, J. E., Ricaldi, J. N., Matthias, M. A., Diaz, M. M., Lovett, M. A. et al. (2003). Leptospirosis: a zoonotic disease of global importance. The Lancet infectious diseases, 3(12), 757-771.

Bradford, M. M. (1976). A rapid and sensitive method for the quantitation of microgram quantities of protein utilizing the principle of protein-dye binding. Analytical biochemistry, 72(1-2), 248-254.

Brasil. Ministério da Saúde. Fundação Nacional de Saúde. (1995). Manual de Leptospirose. Autor.

Brasil. Secretaria de Vigilância em Saúde. (2009). Guia Leptospirose: diagnóstico e manejo clínico. Autor.

Cullen, P. A., Xu, X., Matsunaga, J., Sanchez, Y., Ko, A. I., Haake, D. A., \& Adler, B. (2005). Surfaceome of Leptospira spp. Infection and immunity, 73(8), 4853-4863.

Dewes, C., Silva, J. P. M., Vasconcellos, F. A., Delgado, G. B., Fortes, T. P., Marmitt, I. V. P. et al. (2020a). Padronização de Dot-ELISA para detecção de anticorpos anti-Leptospira em soro bovino. Brazilian Journal of Development, 6(9), 72908-72917.

Dewes, C., Silva, J. P. M., Fortes, T. P., Marmitt, I. V. P., Vasconcellos, F. A., Felix, S. R., \& Silva, Éverton F. (2020b). Prevalence of anti-Leptospira antibodies in cattle confined for exportation. Research, Society and Development, 9(11), e3329119929. https://doi.org/10.33448/rsd-v9i11.9929

Faine, S. Adler, B. Bolin, C., \& Perolat, P. (1999). Leptospira and Leptospirosis. MediSci.

Favero, M., Pinheiro, S. R., Vasconcellos, S. A., Morais, Z. M., Ferreira, F., \& Ferreira Neto, J. S. (2001). Leptospirose bovina: variantes sorológicas predominantes em colheitas efetuadas no período de 1984 a 1997 em rebanhos de 21 estados do Brasil. Arquivos do Instituto Biológico, 68(2), 29-35.

Fenoll, A., Jado, I., Vicioso, D., \& Casal, J. (1997). Dot blot assay for the serotyping of pneumococci. Journal of Clinical Microbiology, 35(3), 764-766.

Ferreira, A. W., \& Ávila, S. L. M. (2001) Sorologia: importância e parâmetros. In: Ferreira AW, Ávila SLM. Diagnóstico laboratorial das principais doenças infecciosas e auto-imunes. (pp.1-8). Guanabara Koogan.

Haake, D. A. (2000). Spirochaetal lipoproteins and pathogenesis. Microbiology, 146(7), 1491-1504.

Heberling, R. L., \& Kalter, S. S. (1986). Rapid dot-immunobinding assay on nitrocellulose for viral antibodies. Journal of clinical microbiology, 23(1), 109113.

Jacobson, R. H. (1998). Validation of serological assays for diagnosis of infectious diseases. Revue Scientifique et Technique-Office International des Epizooties, 17(2), 469-486. 
Juhl, B. R., Nørgaard, T., \& Bjerrum, O. J. (1984). The effect of Tween 20 on indirect immunoperoxidase staining of blood group antigen A in human urothelium. Journal of Histochemistry \& Cytochemistry, 32(9), 935-941.

Lafetá, B. N., Santos, S., Silva, V. L., Carvalho, M. A. R., Diniz, C. G., \& Silva, N. (2008). Determinação do perfil protéico da membrana externa da Leptospira interrogans sorovariedade Hardjoprajitno. Arquivo Brasileiro de Medicina Veterinária e Zootecnia, 60(6), 1301-1306.

Lage, A. P., Leite, R. M. H., Thompson, J. A., Bandeira, D. A., Herrmann, G. P., Moreira, E. C. et al. (2007). Serology for Leptospira sp. in cattle of the State of Paraíba, Brazil. Arquivos do Instituto Biológico, São Paulo, 74(3), 185-190.

Levett, P. N. (2004). Leptospirosis: a forgotten zoonosis?. Clinical and Applied Immunology Reviews, 4(6), 435-448.

Lilenbaum, W., \& Souza, G. N. (2003). Factors associated with bovine leptospirosis in Rio de Janeiro, Brazil. Research in Veterinary Science, 75(3), $249-251$.

Lin, T. M., \& Halbert, S. P. (1986). Rapid dot enzyme immunoassay for the detection of antibodies to cytomegalovirus. Journal of clinical microbiology, 24(1), 7-11.

Marques, A.E., Rocha W. V., Brito, W. M. E. D., Fioravanti, M. C. S,. Parreira, I. M., Jayme, V. S. (2010) Prevalência de anticorpos anti-Leptospira spp. e aspectos epidemiológicos da infecção em bovinos do Estado de Goiás. Ciência Animal Brasileira, 11(3), 607-617.

Magalhães, G. M., Alvarenga, P. B., Medeiros-Ronchi, A. A., Moreira, T. A., Gundim, L. F., Gomes, D. O. et al. (2020). Leptospirosis in slaughtered cows in the Triangulo Mineiro, Minas Gerais: prevalence, serological profile and renal lesions. Bioscience Journal, 36(2), 539-545.

Magalhães, D. F., Silva, J. A., Moreira, E. C., Wilke, V. M. L., Haddad, J. P. A., \& Meneses, J. N. C. (2006). Prevalência de aglutininas anti-Leptospira interrogans em cães de Belo Horizonte, Minas Gerais, 2001 a 2002. Arquivo Brasileiro de Medicina Veterinária e Zootecnia, 58(2), 167-174.

Picardeau, M. (2013). Diagnosis and epidemiology of leptospirosis. Médecine et maladies infectieuses, 43(1), 1-9.

Pimenta, C. L. R. M., Sousa, C. B., Morais, D. A., Silva, M. L. C. R., Nogueira, D. B., Costa, D. F. et al. (2019). Seroprevalence and predominant serogroups of Leptospira sp. in serological tests of ruminants in northeastern Brazil. Semina: Ciências Agrárias, 40(4), 1513-1522.

Pinheiro, R. R. (2001). Vírus da artrite encefalite caprina: desenvolvimento e padronização de ensaios imunoenzimáticos (ELISA e Dot-Blot) e estudo epidemiológico no Estado do Ceará. Doutorado em Ciência Animal, Universidade Federal de Minas Gerais, Belo Horizonte, MG.

Pinheiro, R. R., Gouveia, A. M. G., Yorinori, E. H., \& Andrioli, A. (2005). Comparação de três técnicas de produção do antígeno do lentivírus caprino utilizado no teste de imunodifusão em gel de ágar. Braz J vet Res anim Sci, 42(6), 453-458.

Pinheiro, R. R., Olortegui, C. D. C., GOUVEIRA, A., Araujo, S. C., \& Andrioli, A. (2006). Desenvolvimento de dot-blot para detecção de anticorpos para o vírus da Artrite Encefalite Caprina em caprinos. Revista Portuguesa de Ciências Veterinárias, 101(557-558), 51-56.

Quinn, P. J., Markey, B. K., Carter, M. E., Donnelly, W. J., \& Leonard, F. C. (2005). Microbiologia veterinária e doenças infecciosas. Porto Alegre: Artmed.

Rossi, C. L., Tsang, V. C., \& Pilcher, J. B. (1991). Rapid, low-technology field-and laboratory-applicable enzyme-linked immunosorbent assays for immunodiagnosis of Schistosoma mansoni. Journal of clinical microbiology, 29(9), 1836-1841.

Samrot, A. V., Sean, T. C., Bhavya, K. S., Sahithya, C. S., Chan-Drasekaran, S., Palanisamy, R. et al. (2021). Leptospiral Infection, Pathogenesis and Its Diagnosis-A Review. Pathogens, 10(2), 145.

Souza, M. A., Castro J. R., Tavares, T. C. F., Soares, P. M., Santos, M. P., Silva, H. O. et al. (2012). Padronização e validação de ELISA indireto para o diagnóstico da leptospirose bovina. Bioscience Journal, 28(6), 993-999.

Sykes, J. E., Hartmann, K., Lunn, K. F., Moore, G. E., Stoddard, R. A., \& Goldstein, R. E. (2011). 2010 ACVIM small animal consensus statement on leptospirosis: diagnosis, epidemiology, treatment, and prevention. Journal of Veterinary Internal Medicine, 25(1), 1-13.

World Health Organization. (2003). Human leptospirosis: guidance for diagnosis, surveillance and control . Suiça: Autor.

Zuerner, R., Haake, D., Adler, B., \& Segers, R. (2000). Technological advances in the molecular biology of Leptospira. Journal of Molecular Microbiology and Biotechnology, 2(4), 455-462. 